\title{
Clinical versus Instrumented Reliability of Diagnosis of Acute Compartmental Syndrome in Tibial Fractures
}

\author{
WESAM G. EL INANI, M.D.; YASIR A. RADWAN, M.D.; AHMED S. MOUSTAFA, M.Sc. and \\ HAMADA M. ABD ELAAL, M.Sc.
}

The Department of Orthopaedic Surgery, Faculty of Medicine, Cairo University

\begin{abstract}
Background: Acute compartment syndrome of the leg may be a devastating complication of a tibial fracture. Meticulous and repeated examinations of the patient who has such a fracture are needed to ensure the diagnosis of acute compartment syndrome (ACS). A.C.S. remains challenging in many patients although the "5 Ps" of compartment syndrome; pain, pallor, paralysis, pulselessness, and paresthesia.
\end{abstract}

Aim of Study: To measure intra-compartmental pressure in different compartments in the lower leg in tibial fractures and to correlate it with common clinical findings found in acute compartment syndrome in trial to early detect acute compartment syndrome and to decrease its devastating complications and rate of fasciotomy.

Patients and Methods: This study was conducted on 100 patients referred to the Emergency department having Tibial fracture predisposed to have acute compartment syndrome by measuring intra-compartmental pressure instrumentally using stryker intra-compartmental pressure monitoring system and correlated with clinical picture and detect the percentage of patients need fasciotomy.

Results: The Stryker intra compartmental monitoring system (STIC catheter) has accuracy and easy to measure intra-compartmental pressure and helps us to early detect A.C.S. in the lower leg also to decrease rate of fasciotomy and complications but it is expensive and needs proper training to use it.

Conclusion: The patient who undergoes fasciotomy requires a physical therapy program to regain function. Postoperative care and rehabilitation are just as important as the procedure itself.

Key Words: Acute compartmental syndrome - Tibial fractures.

\section{Introduction}

LOWER extremity compartment syndrome (CS) is characterized by severe pain resulting from increased interstitial pressure within the closed compartments of the leg musculature that impairs

Correspondence to: Dr. Hamada M. Abd Elaal, E-Mail: h.aboyahia@gmail.com local circulation and left untreated results in irreversible peripheral nerve and muscle ischemia [1]

Acute CS is a true surgical emergency that must be treated by decompression fasciotomy without delay to prevent permanent disability, amputation, and death [2]. The diagnosis of acute CS is based on careful clinical examination. Intra-compartmental pressure measurement, and monitoring if indicated, is a recommended clinical practice in uncertain diagnostic situations [3]

Acute compartment syndrome occurs when the tissue pressure within a closed muscle compartment exceeds the perfusion pressure and results in muscle and nerve ischemia. It typically occurs subsequent to a traumatic event, most commonly a fracture [4].

Timely surgery is of up most importance, as inadequate or delayed surgical release may result in further tissue damage and substantial local (e.g., Volkmann's contracture, amputation) or systemic complications (e.g., organ failure, death). Therefore, awareness for the development of ACS and its early diagnosis are of major significance [5].

Compartment syndrome may affect any compartment, including the hand, forearm, upper arm, abdomen, buttock, and entire lower extremity. Almost any injury can cause this syndrome, including injury resulting from vigorous exercise. Clinicians need to maintain a high level of suspicion when dealing with complaints of extremity pain [4].

Aim of the work:

The purpose of this study is to measure intracompartmental pressure in different compartments in the lower leg in tibial fractures and to correlate 
it with common clinical findings found in acute compartment syndrome for early detection of acute compartment syndrome.

\section{Patients and Methods}

This is a prospective study to analyze data of 100 patients referred to the Emergency Department having Tibial fracture predisposed to have acute compartment syndrome by measuring intracompartmental pressure instrumentally using stryker intra-compartmental pressure monitoring system and correlated with clinical picture and detect the percentage of patients who need fasciotomy. This study has been done involving patients with closed tibial fractures in different age groups and Male $=73$ and Female 27. Patients having Systemic diseases are 12.the study has been done from February 2015 to April 2017. The sample consisted of patients who presented to Emergency department in different hospitals in Cairo and several Governorates in Egypt consecutively with closed tibial fractures. Written consent was obtained from the patients for ethical clearance. Patients with Open Tibial fractures, vascular or nerve injury of the limb,crush injury, abdominal surgery, pelvic surgery, spinal surgery and plastic surgery, were excluded from the study. Patient received in the emergency department were immediately subjected to head to foot survey and hemodynamic stabilization was done. Fractured limb was examined clinically for pain on passive stretching, tense compartment, pallor, paraesthesia, paralysis and pulselessness, fracture type has been analysed, mechanism of injury and time of accident or worsening of symptoms and the findings were recorded.

The study included all patients presented with Tibial fractures in all different ages and both sexes. While patients with open Tibial fractures, abdominal surgery, Pelvic surgery, Spinal surgery and Plastic surgery, vascular injury in affected limb, nerve injury in affected limb and crush injuries and Burns were excluded from the study.

\section{Patient counseling:}

A crucial part of the procedure, in which the proposed plan including the investigations necessary for the procedure, the operative details. The patients were informed that they enrolled in a study before surgery with the ability to refuse the participation in the study or to continue participation after being started in it without affecting their management. This counseling was essential to have the maximum cooperation of the patient as well as to decrease the patient anxiety.

\section{Methods:}

All patients were subjected to the following: Full history taking and clinical examination at the time of sampling Careful detection of clinical characteristics of Acute Compartment Syndrome include pain, parethesia, pallor, swelling, pulslessness, Skin changes also Type of fractures, detection time, mechanism of injury, presence or absence of Systemic disease and needed investigations.

Careful and correct measurement of different compartments of lower leg in suspected patients using Stryker intra- compartmental monitoring system; a hand held device directly measuring the intra-compartmental pressure. We Screw the pressure coupler onto the syringe and then firmly attach a side-ported needle to the coupler and Place the assembled syringe-coupler-needle complex into the pressure monitoring device and snap the protective cover on the device shut. Then Purge the air from the syringe-coupler-needle complex by holding it upright at a $45^{\circ}$ angle and slowly compressing the syringe in this position. After turn power on we zeroing the device by pushing its "zero" and wait seconds for proper zeroing then start with compartment of interest and other compartments. The needle should be perpendicular to skin within $5 \mathrm{~cm}$ of fracture site if possible, each compartment has its specific entry as described in literature. We push $0.3 \mathrm{ml}$ saline in the compartment and wait for stabilization of reading then take measurement. We do that for all compartments and repeat measurements for suspected compartments. If pressure is more than $30 \mathrm{mmHg}$ it will be of interest and patient will be closely followed for future decision.

\section{Statistical methods:}

All Data were collected, tabulated and subjected to statistical analysis. Statistical analysis is performed by SPSS in general (version 17), also Microsoft office Excel is used for data handling and graphical presentation.

Quantitative variables are described by the Mean, Standard Deviation (SD), the Range (Maximum - Minimum) and median. Qualitative categorical variables are described by proportions and Percentages. One way analysis of variance (ANOVA) is used for comparing the means of more than two groups. Multiple comparison Bonferroni method is used for comparing each two groups together. Independent samples $t$-test is used for comparing the means of two groups. Significance level is considered at $p<0.05$ (S); while for $p<0.01$ is considered highly significant (HS). Two Tailed 
tests are assumed throughout the analysis for all statistical tests.

\section{Results}

In this study pain presented in all cases and has a highly significant correlation with intra-compartmental pressure of all lower leg compartments.

According to mangled extremity score we classify groups into age below 30 years and from 3050 years and above 50 years. The difference of means between the three groups is statistically significant $(p<0.05)$ as shown in Table (1).

But in Multiple Comparisons using Bonferroni method as shown in Table (2) For Anterior compartment the difference is statistically significant $(p<0.05)$ between the mean pressure of age group older than 50 years and the group between 30 to 50 years. No statistically significant difference can be found between other groups $(p>0.05)$. For Lateral compartment the difference is statistically non significant $(p>0.05)$ between all groups. For Posterior compartment the difference is statistically significant $(p<0.05)$ between the mean pressure of age group below 30 years and the group between 30 to 50 years. No statistically significant difference can be found between other groups $(p>0.05)$.

There is statistically non-significant difference between groups means in all compartments $(p>$ $0.05)$, regarding Effect of gender and swelling on Intra-compartmental pressure in all compartments. There is statistically highly significant difference between any two groups means in all compartments $(p<0.001)$ regarding effect of Pallor and Intracompartmental pressure. Also according to Injury Severity Score (ISS) we classify fracture type to serious, severe and critical. There is statistically highly significant difference between the groups means in all compartments $(p<0.001)$ regarding type of fracture as shown in Table (3).
According to Mangled extremity severity score we classify mechanism of injury into medium, high and very high. There is statistically highly significant difference between the groups means in all compartments $(p<0.001)$.

There is statistically highly significant difference between groups means in all compartments $(p<0.001)$ regarding effect of Pulse and Intracompartmental pressure.

Table (1): Effect of Age on Intra-compartmental pressure, Analysis of variance (ANOVA).

\begin{tabular}{lcccc}
\hline & Mean & SD & F & $p$-value \\
\hline Anterior: & & & & \\
$\quad$ <30yrs & 27.10 & 4.96 & 3.990 & 0.021 \\
30-50yrs & 29.94 & 8.07 & & \\
>50yrs & 22.00 & 2.83 & & \\
Lateral: & & & & \\
$\quad$ <30yrs & 24.55 & 4.88 & 3.259 & 0.042 \\
30-50yrs & 29.10 & 8.85 & & \\
>50yrs & 24.17 & 3.13 & & \\
Posterior: & & & & \\
$\quad$ <30yrs & 24.30 & 5.09 & 4.744 & 0.011 \\
30-50yrs & 29.76 & 8.39 & & \\
$\quad>50 \mathrm{yrs}$ & 24.83 & 3.66 & & \\
\hline
\end{tabular}

Table (2): Effect of age on intra-compartmental pressure, multiple comparisons between each two age group in same compartment using Bonferroni method.

\begin{tabular}{cllll}
\hline & & $\begin{array}{c}\text { Mean } \\
\text { Difference }\end{array}$ & $\begin{array}{c}\text { Std. } \\
\text { Error }\end{array}$ & $\begin{array}{c}p \text { - } \\
\text { value }\end{array}$ \\
\hline $\begin{array}{c}\text { Anterior: } \\
\text { <30yrs }\end{array}$ & 30-50yrs & -2.84 & 1.85 & 0.382 \\
<30yrs & $>50 y r s$ & 5.10 & 3.46 & 0.430 \\
30-50yrs & $>50 y r s$ & 7.94 & 3.14 & 0.039 \\
Lateral: & & & & \\
<30yrs & 30-50yrs & -4.55 & 2.01 & 0.078 \\
<30yrs & $>50 y r s$ & 0.38 & 3.77 & 1.000 \\
30-50yrs & $>50 y r s$ & 4.93 & 3.42 & 0.457 \\
Posterior: & & & & \\
<30yrs & 30-50yrs & -5.46 & 1.92 & 0.016 \\
<30yrs & $>50 y r s$ & -0.53 & 3.60 & 1.000 \\
30-50yrs & $>50 y r s$ & 4.93 & 3.27 & 0.403 \\
\hline
\end{tabular}

Table (3): Effect of fracture type on intra-compartmental pressure.

\begin{tabular}{lccccccc}
\hline & Mean & SD & $\begin{array}{c}\text { Mean } \\
\text { Difference }\end{array}$ & $\begin{array}{c}\text { Std. Error } \\
\text { Difference }\end{array}$ & $t$ & df & $\begin{array}{c}p- \\
\text { value }\end{array}$ \\
\hline $\begin{array}{c}\text { Anterior: } \\
\quad \text { Males }\end{array}$ & 29.24 & 7.66 & 2.33 & 2.33 & 1.00 & 108 & 0.321 \\
$\quad \begin{array}{l}\text { Females } \\
\text { Lateral: }\end{array}$ & 26.92 & 7.35 & & & & & \\
$\quad \begin{array}{l}\text { Males } \\
\text { Females }\end{array}$ & 28.27 & 8.28 & 2.43 & 2.53 & 0.96 & 108 & 0.338 \\
$\begin{array}{c}\text { Posterior: } \\
\quad \text { Males }\end{array}$ & 25.83 & 8.09 & & & & & \\
$\quad$ Females & 25.82 & 8.13 & 2.90 & 2.44 & 1.19 & 108 & 0.237 \\
\hline
\end{tabular}


There is statistically highly significant difference between groups means in all compartments $(p<0.001)$ as shown in Table (4) regarding effect of Detection time on Intra-compartmental pressure.

There is statistically highly significant difference between groups means in all compartments $(p<0.001)$. Regarding Effect of Skin changes and Intra-compartmental pressure, Independent Samples $t$-test as shown in Table (5).

As shown in Table (6), there is statistically highly significant difference between groups means in all compartments $(p<0.001)$ regarding effect of Parethesia and Intra-compartmental pressure.

Table (4): Effect of detection time on intra-compartmental pressure, independent samples $t$-test.

\begin{tabular}{lccccccc}
\hline & Mean & SD & $\begin{array}{c}\text { Mean } \\
\text { Difference }\end{array}$ & $\begin{array}{c}\text { Std. Error } \\
\text { Difference }\end{array}$ & $t$ & df & $\begin{array}{c}p- \\
\text { value }\end{array}$ \\
\hline $\begin{array}{l}\text { Anterior: } \\
\quad<12 \mathrm{~h} \text { post injury }\end{array}$ & 28.16 & 7.02 & -13.13 & 2.71 & -4.84 & 108 & 0.000 \\
$\quad>12 \mathrm{~h}$ post inhury & 41.29 & 5.65 & & & & & \\
$\quad \begin{array}{l}\text { Lateral: } \\
\quad \text { <12h post injury }\end{array}$ & 27.12 & 7.65 & -13.88 & 2.95 & -4.70 & 108 & 0.000 \\
$\quad>12 \mathrm{~h}$ post inhury & 41.00 & 5.72 & & & & & \\
$\quad \begin{array}{l}\text { Posterior: } \\
\quad<12 \mathrm{~h} \text { post injury }\end{array}$ & 27.67 & 7.36 & -13.04 & 2.87 & -4.54 & 108 & 0.000 \\
$\quad>12 \mathrm{~h}$ post inhury & 40.71 & 7.34 & & & & & \\
\hline
\end{tabular}

Table (5): Effect of skin changes and Intra-compartmental pressure, independent samples $t$-test.

\begin{tabular}{|c|c|c|c|c|c|c|c|}
\hline & Mean & SD & $\begin{array}{c}\text { Mean } \\
\text { Difference }\end{array}$ & $\begin{array}{l}\text { Std. Error } \\
\text { Difference }\end{array}$ & $t$ & df & $\begin{array}{c}p- \\
\text { value }\end{array}$ \\
\hline \multicolumn{8}{|l|}{ Anterior: } \\
\hline Absent & 26.61 & 5.58 & -14.56 & 1.39 & -10.45 & 108 & 0.000 \\
\hline Present & 41.17 & 4.37 & & & & & \\
\hline \multicolumn{8}{|l|}{ Lateral: } \\
\hline Absent & 25.36 & 5.92 & -16.14 & 1.47 & -10.98 & 108 & 0.000 \\
\hline Present & 41.50 & 4.34 & & & & & \\
\hline \multicolumn{8}{|l|}{ Posterior: } \\
\hline Absent & 25.89 & 5.41 & -15.94 & 1.39 & -11.48 & 108 & 0.000 \\
\hline Present & 41.83 & 5.28 & & & & & \\
\hline
\end{tabular}

Table (6): Effect of parethesia and intra-compartmental pressure, independent samples $t$ test.

\begin{tabular}{cccccccc}
\hline & Mean & SD & $\begin{array}{c}\text { Mean } \\
\text { Difference }\end{array}$ & $\begin{array}{c}\text { Std. Error } \\
\text { Difference }\end{array}$ & $t$ & df & $\begin{array}{c}p \text { - } \\
\text { value }\end{array}$ \\
\hline $\begin{array}{c}\text { Anterior: } \\
\text { Absent }\end{array}$ & 26.13 & 4.68 & -14.33 & 1.20 & -11.95 & 108 & 0.000 \\
Present & 40.45 & 6.27 & & & & & \\
Lateral: & & & & & & & \\
Absent & 24.83 & 5.23 & -15.85 & 1.26 & -12.59 & 108 & 0.000 \\
Present & 40.68 & 5.49 & & & & & \\
Posterior: & & & & & & & \\
Absent & 25.44 & 4.76 & -15.28 & 1.22 & -12.48 & 108 & 0.000 \\
Present & 40.73 & 6.47 & & & & & \\
\hline
\end{tabular}




\section{Case presentation:}

5 cases are presented; each one fulfills inclusion and exclusion criteria also presented at Emergency Department then after taking a consent and full history and careful general examination we will do serial measurement of intra-compartment pressure of suspected compartments.

\begin{tabular}{ll}
\hline Age & - 45 years \\
Sex & - Male \\
$\begin{array}{c}\text { Mechanism } \\
\text { of injury }\end{array}$ & - R.T.A \\
Fracture site & $\begin{array}{l}\text { - Plain X-ray showing major fracture right } \\
\text { tibial plateau schatzyker type } 6\end{array}$ \\
$\begin{array}{c}\text { Clinical } \\
\text { presentation }\end{array}$ & $\begin{array}{l}\text { Sever pain out of proportion, swelling, skin } \\
\text { changes, pallor, parethesia, irrelevant history } \\
\text { of systemic disease, not palpable pulse and } \\
\text { detection time less than 12 hours }\end{array}$ \\
&
\end{tabular}

(A)

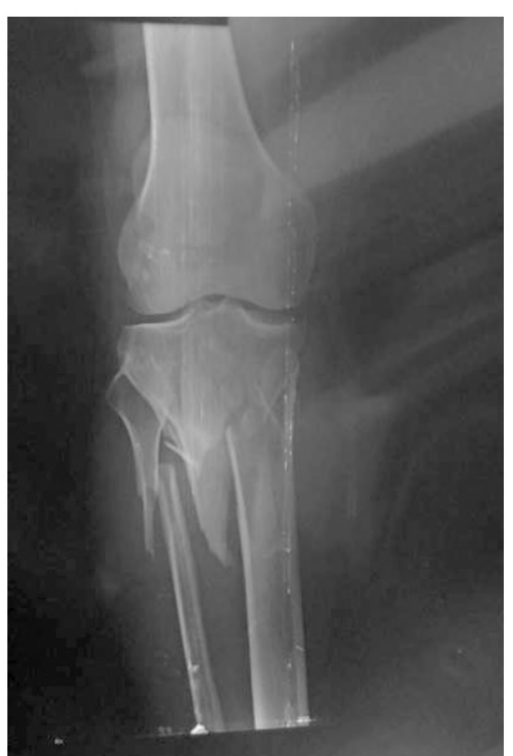

Intra-compartmental pressure after serial measurement:

Main intra-compartmental pressure using stryker device of (anterior compartment $=47 \mathrm{~mm}$ gh, lateral compartment $=40 \mathrm{mmgh}$ and posterior compartment $=41$ ).

\section{Interference:}

Emergent fasciotomy then after good decompression of all leg compartments.

\section{Prognosis:}

Good prognosis fracture is fixed with suitable plate and screws fixation, lastly directed to proper rehabilitation programme.

(B)

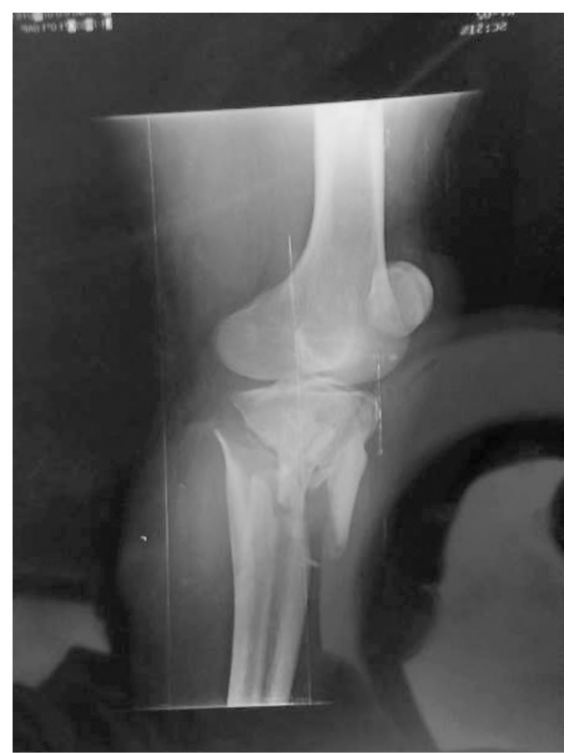

Fig. (1): P.X.R fracture Tibial plateau schatzyker type 6.

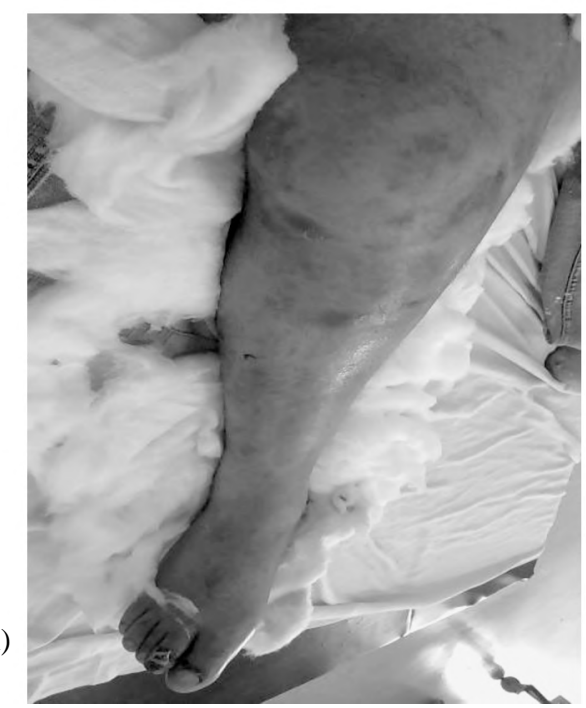

(B)

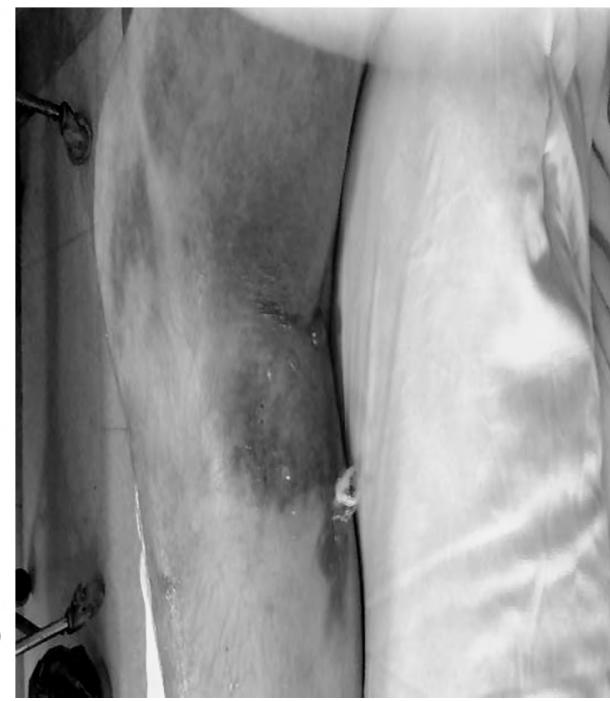

Fig. (2A,B): Showing swelling, pallor and skin changes (bullae at back of knee). 

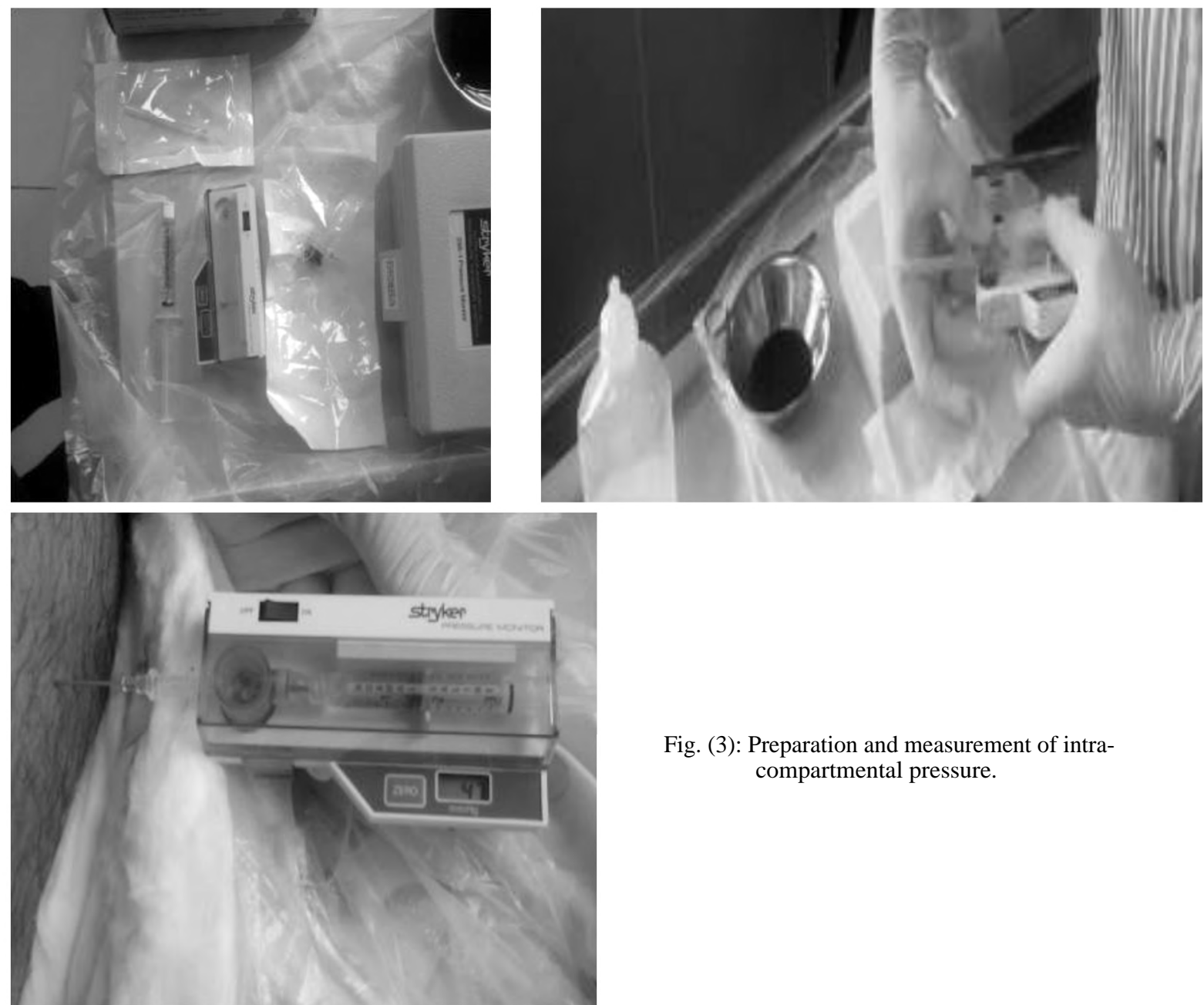

Fig. (3): Preparation and measurement of intracompartmental pressure.

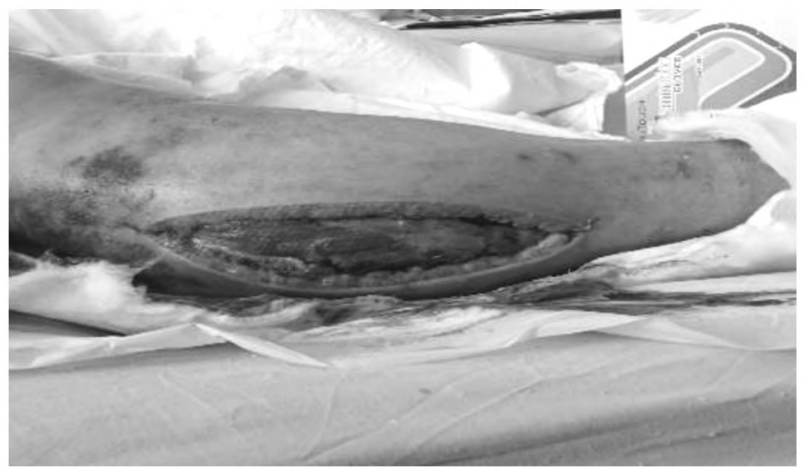

Fig. (4): Showing leg muscles at time of fasciotomy and later on

\section{Discussion}

Acute compartment syndrome from any cause occurs most commonly in the lower leg and most often follows a fracture of the tibia [6].

The most important step in diagnosing a compartment syndrome is the clinician's awareness. In patients at risk for a compartment syndrome, repeated examinations are required to allow for this dynamic process. In patients with uncertain signs, invasive measurement of intra-compartmental pressure is available [7]. In our study we found that pain out of proportion in all cases has strong correlation with elevation of intra-compartmental pressure and strong indicator of possibility of acute compartment syndrome occurrence although it is difficult to assess in pediatric patients and severe painful fractures.

Also we found in this study Parethesia (present in 21 cases) and pulselessness (absent in 71 cases) and pallor (present in 58 cases) are extremely have direct correlation with increased intra-compartmental pressure in tibial fractures using stryker hand held device. This is in agreement with the literature $[6,8]$. In which they said that said that, although clinical signs; like pain on passive stretch, pallor and tense compartment, help in diagnosing ACS, they may be absent in some cases, indicating that the clinical signs are better at excluding than confirming a diagnosis.

Also said that in their study, increasing leg pain was the main clinical symptom in patients with 
ACS, followed by paresthesia and motor weakness of leg muscles. Furthermore, absolute measures of intra-compartmental pressures of leg compartments were higher than $30 \mathrm{mmHg}$ in $92 \%$ of patients [6,8] In our study we detect that age below 50 years $(92$ cases) is at risk in comparison of more than 50 years (8 cases).

But Mc Queen et al., in different studies also identified age as a significant risk factor with an average age of 30 years among patients with ACS with a tibia fracture [9-13]. In our study we detect that severity of fractures and high energy trauma (41 cases) have strong correlation and increase incidence of ACS occurrence and this has disagreement with the literature, who reported that lowenergy tibia fractures are actually at a higher risk of ACS than their high-energy counterparts [9] whereas has agreement with the literature, who reported an equal incidence of ACS with high and low energy fractures Because These mechanisms carry substantial energy, which is transferred to the soft tissues, producing contusion, swelling, and inflammation and who reported that there is no doubt that multiple injuries that affect a number of anatomical sites have a profound effect on the homeostasis of the body and the ensuing "chemical storm": Systemic inflammatory response syndrome (SIRS) versus compensatory anti-inflammatory response syndrome (CARS) and endothelial damage is linked with occurrence of ACS [5].

In our study we exclude open tibial fractures in agreement with literature which reported that although there is a risk of ACS with any type of tibia fracture, an open fracture is anecdotally considered to have de facto decompressed the compartments, and is therefore unlikely to cause an ACS The auto decompression phenomenon that occurs with a high-grade open tibia fracture is hypothesized to cause an effect similar to a fasciotomy [14]. In our study we found that there is no influence of gender to increase incidence of ACS and we in agreement with Park who reported that the popular belief is that ACS is more likely to occur in young males [10]. In our study we found that women were just as likely as men to get ACS following their tibial fractures. However, we also found that ACS occurred more readily in younger patients. This we think is due to younger people having larger muscle bulk within a tight fascia with very little room to expand before the intracompartmental pressure rises [14].

Also in this study we found that detection time of ACS has strong and beneficial correlation to decrease faciotomy rate and complications of ACS and faciotomy and also we in agreement with
Ramprasath who reported that the duration of pressure elevation is fully as important in the production of neuromuscular deficits as is the magnitude of pressure elevation. Pressures that are benign for a few hours may be detrimental if allowed to persist for longer periods. Thus, serial monitoring of tissue pressure provides clinically useful information as to the trend of ICP. Muscles tolerate 4 hours of ischemia well, but by 6 hours the result is uncertain, after 8 hours, the damage is irreversible, hence the early diagnosis becomes important [15]. Also in our study we found that Skin changes and presence of systemic disease have strong correlation with increase intracompartmental pressure but swelling has insignificant correlation with it.

Lastly in agreement with our study in that the Stryker intra-compartmental monitoring system (STIC catheter) has accuracy and easy to measure intra-compartmental pressure but it is expensive and needs proper training to use it $[\mathbf{1 5 , 1 6 ]}$. Correlation of a clinical presentation of Acute Compartment Syndrome to intra-compartmental pressure measurement in 100 cases be suspected to have ACS is a strength point for our study. On the other hand the expensiveness, invasiveness and less availability of device and its disposable set make weak point and difficulty in our study.

\section{Conclusion:}

The Stryker intra compartmental monitoring system (STIC catheter) has accuracy and easy to measure intra-compartmental pressure and helps us to early detect A.C.S. in the lower leg also to decrease rate of fasciotomy and complications but it is expensive and needs proper training to use it.

The patient who undergoes fasciotomy requires a physical therapy program to regain function. Postoperative care and rehabilitation are just as important as the procedure itself.

\section{References}

1- VIA A.G., OLIVA F., SPOLITI M. and MAFFULLI N.: Acute compartment syndrome. Muscles Ligaments Tendons J., 5: 18-22, 2015.

2- RAZA H. and MAHAPATRA M.: A. Acute compartment syndrome in orthopedics: Causes, diagnosis, and management. Adv. Orthop., 543412, 2015.

3- GARNER M.R., TAYLOR S.A., GAUSDEN E. and LYDEN J.P.: Compartment syndrome: Diagnosis, management, and unique concerns in the twenty- first century. HSS J., 10: 143-52, 2014.

4- TEKWANI K. and SIKKA R.: High-risk chief complaints III: Abdomen and extremities. Emerg. Med. Clin. North Am., Nov. 27 (4): 747-65, 2009. 
5- SELLEI R.M., HINGMANN S.J., KOBBE P., WEBER C., et al.: Compartment elasticity measured by pressurerelated ultrasound to determine patients "at risk" for compartment syndrome: An experimental in vitro study. Patient Saf Surg., 9: 4, 2015.

6- SHADGAN BABAK, GAVIN PEREIRA, MATTHEW MENON, et al.: Risk factors for acute compartment syndrome of the leg associated with tibial diaphyseal fractures in adults J. Orthopaed Traumatol 16: 185-192 This article is published with open access at Springerlink.com, 2015.

7- FRINK M., HILDEBRAND F. and KRETTEK C.: Compartment syndrome of the lower leg and foot. Clin. Orthop. Relat. Res., 468: 940, 2010.

8- OLSON S.A. and GLASGOW R.R.: Acute compartment syndrome in lower extremity musculoskeletal trauma. J. Am. Acad. Orthop. Surg., 13: 436, 2005.

9- McQUEEN M.M. and COURT-BROWN C.M.: Compartment monitoring in tibial fractures. The pressure threshold for decompression. J. Bone Joint Surg. Br., Jan. 78 (1): 99-104, 1996.

10- McQUEEN M.M., GASTON P. and COURT-BROWN C.M.: Acute compartment syndrome. Who is at risk? J. Bone Joint Surg. Br., 82: 200, 2000.
11- McQUEEN M.M. and COURT-BROWN C.M.: Early diagnosis of compartment syndrome: Continuous pressure measurement or not? Injury, 41: 431-2, 2010.

12- McQUEEN M.M., DUCKWORTH A., AITKEN and COURT-BROWN C.M.: The estimated sensitivity and specificity of compartment pressure monitoring for acute compartment syndrome. J. Bone Joint Surg. Am., 95: 673677, 2013.

13- McQUEEN M.M., DUCKWORTH A.D., AITKEN S.A., et al.: Predictors of compartment syndrome after tibial fracture. J. Orthop. Trauma, 29: 451-5, 2015.

14- PARK S., AHN J., GEE A.O., et al.: Compartment syndrome in tibial fractures. J. Orthop. Trauma, 23: 514, 2009.

15-RAMPRASATH D.R., THIRUNARAYANAN V., DAVID J. and ANBAZHAGAN S.: Malaysian Orthopaedic Journal Vol 10 No 1Effectiveness of Serial Measurement of Differential Pressure in Closed Tibial Diaphyseal Fractures in Diagnosing Acute Compartment Syndrome using Whiteside's Technique, 2016.

16- MATTHEW A. HALANSKI, M.D., MICHAEL R. MORRIS, M.D., BENJAMIN LEE HARPER, M.D. and CHRISTOPHER DORO, M.D. Based on an original article: J. Bone Joint Surg. Am., Oct. 1; 96 (19): e 171, 2014.

\section{المتلازمة الحادة لحيز عضلات الساق فى حالات كسر القصبة

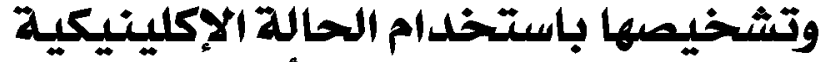 مقابل استخلام الأجهزة}

\footnotetext{
المقدمة: قد تكمن متلازمة الصيز العضلى الحاد فى العاق من المضاعفات المدمرة لكسر قصبة الساق. هناك حاجة لفحوصات دقيقة

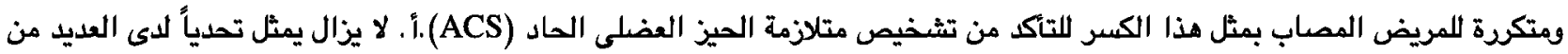

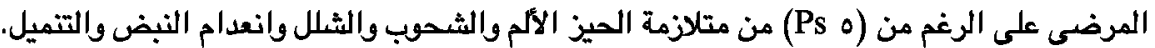

الهدف من الدراسة: قياس الضفط داخل الصيز العضلى فى أقسام مختلفة فى أسفل السات فى كسهد قصبة الساق وربطة بالنتائج السريرية

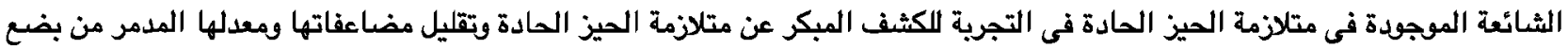

المرضنى والطرقة: أجريت هذه الدراسة على . . ا مريض تم تصويلهم إلى قسم الطوارئ ويعانون من كسر فى قصبة الساق والذين لديهم

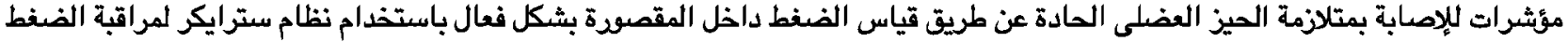

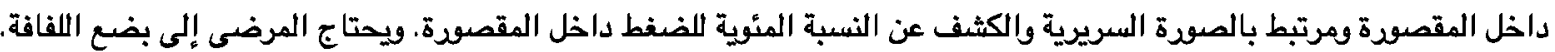
النتائج: يتمتع نظام سترايكر للمراقبة داخل المقصودة (تسطرة STIC) بالدقة وسهولة قياس الضغط داخل الصجرات ويساعدنا على ألى الكشف المبكر عن في أسفل الساق أيضاً لتقليل معدل بضع اللفافة والمضاعفات ولكنها مكفة وتحتاج إلى تلريب مناسب لامتخدامها.

الخلاصة (الاستتاج): يحتاج المريض الذى خضع لبضع اللفافة إلى برنامج علاج طبيعى لاستعادة الوظيفة. ولا تقل الرعاية وإعادة التأهيل بعد الجراحة أهمية عن الإجراء نفسها.
} 